\title{
ЕКАТЕРИНА КАРАСЬ
}

\section{К вопросу о защите права общей долевой собственности}

Основной закон, как нам известно, представляет собой свод незыблемых и священных правил, которые подлежат безукоснительному соблюдению. В Конституции РФ закреплен постулат о том, что каждый вправе иметь имущество в собственности, владеть, пользоваться и распоряжаться им как единолично, так и совместно с другими лицами. Так, в последнее время в Российской Федерации всё большую и большую актуальность приобретают вопросы общей собственности. С переходом к рыночной экономике институт права собственности претерпел значительные изменения, в том числе широко стали распространяться гражданско-правовые отношения, касающиеся общей долевой собственности. На развитие этой категории повлияли процессы приватизации, в том числе и жилого фонда, новый порядок управления многоквартирными домами, развитие наследственного права и ряд других факторов.

\section{1. Понятие права общей долевой собственности}

Институт права общей собственности своими корнями уходит в римское право, которое допускало, что вещь и право на неё могут принадлежать нескольким лицам одновременно. Такие отношения римские юристы называли communion (общность) ${ }^{1}$.

Право общей долевой собственности, как и право собственности в целом, можно понимать как в объективном, так и в субъективном смысле. В объективном смысле оно представляет собой совокупность норм, регулирующих отношения по принадлежности единой вещи двум или более лицам одновременно в определенных долях,

1 И. Новицкий, Римское право, Москва 1996, С. 100. 
320 | Adam Mickiewicz University Law Review

а субъективном - право двух или более лиц сообща по своему усмотрению владеть, пользоваться, распоряжаться принадлежащим им имуществом как единым целым ${ }^{2}$.

Следует отметить, что фактически ни один из поименованных в ГК РФ (Гражданский кодекс Российской Федерации) и других законодательных актах договоров не имеет своей единственной целью установление общей собственности в том или ином виде. Общая собственность возникает как явление сопутствующее какому-либо соглашению (например, договор простого товарищества) или иному факту (например, открытие наследства).

\section{2. Проблемы правового регулирования института права общей долевой собственности}

Несмотря на свою распространенность, институт общей долевой собственности содержит в себе проблемы как теоретического, так и практического плана. По этому поводу еще Г.Ф. Шершеневич отмечал, что общая собственность, явление весьма частое, представляет значительные трудности для уяснения ее юридической природы ${ }^{3}$.

Главной теоретической проблемой в настоящее время является природа долей в праве общей долевой собственности. Как отмечает М.Ю. Козлова: законодатель не дает четкого ответа на вопрос о том, что такое доля, поскольку из норм ГК РФ следует, что доля может относиться как к праву, так и к имуществу ${ }^{4}$. В свою очередь, Постановление Конституционного Суда РФ № 5-П (дата выдачи - 13.03.2008) по этому поводу гласит: в Гражданском кодексе Российской Федераџии под долей понимается не доля в имуществе, а доля в праве общей долевой собственности ${ }^{5}$. Однако, данный вопрос является очень дискуссионным и требует изучения в отдельной работе.

В практическом плане право общей долевой собственности также заключает в себе неразрешенные до настоящего времени проблемы и вопросы.

\section{1 Защита прав участников общей долевой собственности}

Одним из таких вопросов является механизм защиты прав участников общей долевой собственности. Право собственности представляет собой абсолютное право, которое должно охраняться от любого вмешательства извне. Только по решению суда собственник может быть лишен своего права. Если человек имеет в собственности

2 Е.С. Корчагина, Распоряжение имущзеством, принадлежащчим лицу на праве общей собственности, Вестник РУДН. Сер. Юрид. науки. 5/ 2007, С. 155.

3 Г.Ф. Шершеневич, Учебник русского гражданского права, Москва 1995, С. 214.

4 М.Ю. Козлова, О неопределенности норм Гражданского кодекса Российской Федерации о праве общей собственности, Гражданское право 5/2012, С. 39

5 СЗ РФ 2008. № 12, Ст. 1183. 
какую-либо вещь, несет бремя её содержания, он всегда будет расценивать вмешательство других людей в сферу своего владения как посягательство на свои естественные и неотделимые права. Не является исключением и право общей долевой собственности. При этом оно обладает одной очень важной особенностью, касающейся тех субъектов, от которых приходится защищаться сособственникам. Традиционно право собственности защищается от посягательств третьих лиц, а вот в праве общей долевой собственности требуется и защита участников этого самого права друг от друга. Особенно неприемлемо, что между участниками общей собственности происходят конфликты, ведь сособственники, наоборот, должны объединять свои усилия, чтобы противостоять угрозам посягательства извне.

Если говорить о защите прав сособственников от посягательств со стороны друг друга, то можно сделать вывод о том, что виндикационный иск здесь не применим, как и любой другой вещно-правовой иск, так как данная конструкция противоречит пониманию права общей долевой собственности, которое по своей природе едино как любое право собственности, то есть сособственники являются субъектом одного и того же права и не могут стать беститульными владельцами по отношению друг к другу. Хотя и существует противоположная точка зрения, указывающая, что иски к другим сособственникам вытекают не из права собственности как права вещного и абсолютного, а из правоотношения, имеющего тип обязательственной связи торое существует между сособственниками. Однако Постановление Президиума ВАС РФ № 5910/11 (дата выдачи - 25.10.2011) идет по пути непризнания договорных связей между сособственниками, при этом указывая на особый характер правоотношений, существующих между участниками общей долевой собственности 7

Механизм защиты прав сособственников друг от друга, исходя из положений части первой Гражданского кодекса РФ $\Phi^{8}$, может включать такие средства как иски о выделе доли из общего имущества, о разделе общего имущества, о переводе на себя прав покупателя отчуждаемой доли при нарушении права преимущественной покупки. Также отмечается, что:

участникам общей долевой собственности предоставлено право на обращение в суд с требованием определения порядка владения и пользования объектом права, а также с требованием о компенсации, соразмерной доли в праве, при невозможности предоставления указанных правомочий․

6 К. Скловский, Собственность в гражданском праве, Москва 2010, С. 261.

7 Вестник ВАС РФ. 2012 № 2.

8 СЗ РФ 1994. № 32, Ст. 3301.

9 Е.С. Корчагина, Распоряжение имуществом..., С. 157. 
322 | Adam Mickiewicz University Law Review

Как представляется, при определении порядка владения и пользования не всегда возможно соответствие так называемых реальных и идеальных долей в имуществе. Поэтому, в том случае, если реальная доля в имуществе, порядок пользования которой определен судом, меньше идеальной, сособственник, владеющий данной долей, вправе потребовать, чтобы иные участники долевой собственности, в фактическом владении и пользовании которых находится недостающая часть идеальной доли, выплатили денежную компенсацию. Данный тезис подтверждается нормами ГК РФ (ст. 247).

Теперь перейдем к вопросу защиты права общей долевой собственности от третьих лиц.

Защита прав сособственников от третьих лиц может потребоваться в том случае, если вещь отчуждена неуправомоченным на это участником общей долевой собственности. В таком случае можно говорить, что приобретатель такой вещи безосновательно владеет ею а, следовательно, сособственник, права которого нарушены, может потребовать отобрание вещи у беститульного владельца и возврата её во владение всех субъектов права общей долевой собственности. Но ведь среди этих субъектов находится и сособственник, который распорядился общей вещью без учета права преимущественной покупки остальных сособственников с нарушением положения об осуществлении правомочий с согласия всех участников. А.В. Егоров предлагает следующий вариант разрешения данной проблемы:

вещь должна возвращаться истцу, заявившему соответствующий иск (...) истец, выигравший дело и отобравший вещь у приобретателя, вправе ее удерживать до тех пор, пока по новому соглашению всех сособственников или в судебном порядке не будет установлено вновь, у кого во владении будет находиться общая вещь ${ }^{10}$.

Представляется, что решение данной проблемы указанным способом позволяет в достаточной мере учесть интересы сособственников, которые пострадали от недобросовестных действий другого сособственника.

В том случае, если отчуждателем выступает третье лицо, во владении которого оказалась вещь и которого сособственники не управомочивали на распоряжение данной вещью от их имени, то проблема также разрешается путем предъявления виндикационного иска. На наш взгляд, такой иск могут подать как все сособственники, так и один из них при согласии всех остальных.

10 А.В. Егоров, Общая долевая собственность: механизм защиты прав сособственников, Вестник гражданского права 4/2012, С. 32. 


\section{2 Виндикация доли в праве}

Хотелось бы отметить, что по вопросу применения норм ГК РФ о виндикационном иске в рамках права общей долевой собственности судебная практика идет по двум направлениям.

С одной стороны, суды придерживались мнения, что виндикация доли в праве невозможна. Так, в определении Высшего Арбитражного Суда РФ от 15.10.2008 № $13265 / 08^{11}$ указывается, что предметом виндикационного иска может быть только индивидуально-определенное имущество, а доля в праве общей собственности на это имущество не может быть предметом истребования из чужого незаконного владения. Кроме того, суд ссылается на пункт 1 статьи 246 и пункт 1 статьи 247 ГК РФ, в которых предусмотрено, что владение, пользование и распоряжение имуществом, находящимся в долевой собственности, осуществляется по соглашению всех ее участников, а так как остальные участники законность владения приобретателя не оспаривают и не давали согласие на истребование данного имущества, то и о виндикации самой вещи тут речи быть не может.

Однако 29 апреля 2010 г. вышло совместное Постановление Пленума Верховного Суда РФ и Пленума Высшего Арбитражного Суда РФ от 09.02.2010 № 10/22 О некоторых вопросах, возникающих в судебной практике при разрешении споров, связанных с защитой права собственности и других вещных прав ${ }^{12}$, в пункте 42 которого указывается, что при рассмотрении требования о возврате доли по аналогии закона подлежат применению статьи 301, 302 ГК РФ. Вскоре, после выхода этого постановления, суды стали выносить решения о присуждении утраченной доли. Постановление Президиума ВАС РФ от 09.02.2010 № 13944/09 указывает, что:

поскольку законодательство допускает такой вид имущества, как доля в праве собственности на неделимую вещь, при нарушении права на данный вид имущества его обладателю должна быть обеспечена защита ${ }^{13}$.

Концепция развития гражданского законодательства о вещном праве, предложенная в 2009 году Советом при Президенте РФ по кодификации и совершенствованию гражданского законодательства, также указывала на необходимость закрепления в законе возможности обладания сособственником перед третьими лицами всеми правами собственника. Кроме того, в ней говорилось и о том, что:

сособственник вправе предъявлять без согласия иных сособственников иски о защите права собственности, в том числе в случаях, когда тревожится вла-

11 Определение Высшего Арбитражного Суда РФ. СПС КонсультантПлюс.

12 Вестник ВАС РФ 2010. № 6.

13 Вестник ВАС РФ 2010. № 5. 
324 | Adam Mickiewicz University Law Review

дение и пользование тех частей вещи, которые в силу соглашения участников общей собственности находятся во владении и пользовании других сособственников ${ }^{14}$.

На наш взгляд, данная позиция выглядит достаточно убедительной, так как в том случае, если сособственник лишается доли в праве общей долевой собственности, то он автоматически лишается и права на конкретную часть имущества, соответствующую доле. Кроме того, аргументом в пользу виндикации доли в праве может послужить и тот факт, что если законодательно в РФ разрешена долевая собственность, то её участникам должны быть предоставлены те механизмы защиты, которые могут быть использованы единоличными собственниками вещи, так как это будет способствовать универсальному применению гражданского законодательства. Следовательно, невозможность использования виндикационного иска привела бы к тому, что участники долевой собственности остались бы в ущемленном положении по сравнению с теми собственниками, которые владеют вещью единолично.

\section{3 Возможность применения института недействительности сделок для защиты прав участников долевой собственности}

Говоря о механизме защиты прав участников общей долевой собственности, невозможно обойти вопрос о применении к данному институту норм о недействительности сделок. Как известно, ст. 246 ГК РФ гласит о том, что распоряжение всем имуществом, находящимся в общей долевой собственности осуществляется только по согласию всех сособственников. Таким образом, в случае, если какой-либо сособственник распорядился всей вещью без ведома других участников общей собственности, они могут защищать свои права с помощью виндикационного иска, как было сказано выше. А может ли пострадавшая сторона восстановить своё право с помощью иска о недействительности сделки? Для ответа на данный вопрос нам нужно обратиться к действующим нормам о недействительности сделок, закрепленным в ГК РФ.

Так, статья 168 ГК закрепляет правило, согласно которому сделка может быть признана недействительной, если она противоречит закону или иным нормативно-правовым актам. Казалось бы, под данную формулировку можно подвести и тот случай, когда один из сособственников без согласия других сособственников распорядился вещью. Но, исходя из смысла института недействительности сделок, заявить о ней может только сторона по сделке. Однако пострадавший сособственник таковой не является. Поэтому, на наш взгляд, в данном случае говорить о таком механизме защиты не приходиться.

14 Концепция развития законодательства о вещном праве (проект), рекомендован Президиумом Совета при Президенте РФ по кодификации и совершенствованию гражданского законодательства (протокол № 3 от 18.03.2009), Вестник ВАС РФ 2009. № 4, С. 88-185. 
Невозможно, в том случае, если сособственник нарушил право других участников общей долевой собственности на преимущественную покупку его доли, говорить и применении к данным отношениям ст. 174 ГК РФ. Как известно, данная статья закрепляет положение о превышении лицом полномочий, установленных договором или учредительными документами. Но требование о преимущественном праве законодательно закреплено в ст. 250 ГК РФ, следовательно, к таким отношениям целесообразнее было бы применить статью 168 ГК РФ. Однако из вышеуказанного следует, что пострадавший сособственник таким механизмом защиты воспользоваться не сможет.

Подводя итог рассмотрению вопроса о защите права общей долевой собственности средствами, предложенными институтом недействительности сделок, можно сделать вывод о том, что для таковых отношений он не подходит в силу специфики субъектного состава.

Резюмируя вышесказанное, хотелось бы отметить, что институт защиты права общей долевой собственности должен развиваться. Для устранения существующих до сих пор противоречий требуется закрепление основных способов её защиты в гражданском законодательстве, как это и предложено было сделать в вышеназванной Концепции. Ведь право общей собственности, равно как и право собственности в целом, священно. И этот ореол святости формировался не одно десятилетие и даже не один век. Предпосылки для признания права собственности священным, безусловно, имеются: данное право обладает абсолютным характером защиты, то есть оно неприкосновенно. Хоть в современных конституциях и нет упоминаний о священности данного права, в любой из них оно закреплено в одном ряду с такими неотъемлемыми правами как, например, право на жизнь. И правоприменителю, и законодателю надлежит использовать все имеющиеся у них в арсенале правовые средства, чтобы сособственники без опаски принимали на себя всё то бремя и те риски, которые неразрывно связаны с любым правом собственности.

\section{Биографическая аннотация:}

Екатерина Карась - Иркутский государственный университет, Юридический институт. Научные интересы: проблемные вопросы института права собственности, долевое строительство многоквартирных домов, договор лизинга и др.

\section{SUMMARY}

\section{The protection of the right to property in co-ownership}

The aim of the study is to evaluate the form of co-ownership in the civil law of the Russian Federation. The author present the concept of sharing property right and the problems related to with a special emphasis on the protection of the right to property, vindication and invalidity of transactions.

KEYWORDS: co-ownership, property right, civil law 
